\title{
Strategi Pengembangan Usaha DNI Skincentre Renon dengan Penerapan Metode Swot dan Topsis
}

DNI Skin Centre Renon Business Development Strategies by Applying Swot and Topsis Methods

Ni Luh Firdayanti, Agung Suryawan Wiranatha*, Cokorda Anom Bayu Sadyasmara PS Teknologi Industri Pertanian, Fakultas Teknologi Pertanian, Universitas Udayana, Kampus Bukit Jimbaran, Badung, Kode pos : 80361; Telp/Fax : (0361) 701801.

Diterima 18 Oktober 2019 / Disetujui 08 Nopember 2019

\begin{abstract}
The development of beauty trends in Indonesia is increasing, which makes the cosmetics industry one of the promising industries. The presence of foreign brand cosmetics makes domestic products experience sales decline. The high level of competition has become one of the factors in conducting business development strategies. The objectives of this study are 1) to analyze the internal and external environmental conditions of DNI Skin Centre, and 2) to formulate strategies and set priorities for DNI Skin Centre business development strategies. This study uses the SWOT method to determine the alternative strategies used, and the TOPSIS method to rank alternative strategies. Strategies that can be applied at DNI Skin Centre Renon are to growth and build. The first alternative priority strategy chosen is to provide education to consumers about Renon's DNI Skin Center products and treatments. The second priority alternative strategy chosen is to maintain the price and quality of the product and the third priority alternative strategy is to promote the products and treatments that exist at the Renon DNI Skin Center.
\end{abstract}

Keywords: Skin Centre, Business Development Strategy, SWOT, TOPSIS

\footnotetext{
*Korespondensi Penulis:

Email : agung_suryawan@unud.ac.id
} 


\section{PENDAHULUAN}

Kosmetik adalah bahan atau sediaan yang digunakan pada bagian luar tubuh manusia (epidermis, rambut, kuku, bibir, dan organ genital bagian luar) untuk membersihkan, mewangikan, mengubah penampilan dan menghilangkan bau badan, melindungi dan memelihara tubuh pada kondisi baik, berdasarkan Pasal 1 ayat 1 Peraturan Menteri Kesehatan Nomor 1176/Menkes/Per/VIII/2010 tentang notifikasi kosmetika. Kosmetik berdasarkan kegunaannya untuk merawat kulit dibedakan menjadi dua yaitu kosmetik perawatan kulit (skin Centre cosmetic) dan kosmetik riasan (decorative and make-up) (Tranggono et al., 2007). Perubahan lingkungan yang cepat menuntut perusahaan untuk beradaptasi secara cepat pula dengan melakukan perbaikan terus menerus melalui inovasi baru (Manurung, 2010). Pertumbuhan industri kosmetik yang berkembang di Indonesia terdiri atas produk asing dan produk lokal. Jumlah produk asing yang beredar di Indonesia sebesar 14.658 dari keseluruhan produk kosmetik yang berkembang di Indonesia sebesar 36.642 hampir setengahnya dikuasai oleh produk asing, sehingga kosmetik dengan merek lokal perlu meningkatkan daya saing (Nabila et al., 2018).

Salah satu industri kecantikan yang berkembang di Indonesia khususya di Bali adalah DNI Skin Centre. DNI Skin Centre didirikan oleh Dr. dr. I Gusti Nyoman Darmaputra Sp.KK, pada 14 Februari 2011. DNI memiliki beberapa cabang di pulau Bali dan Jawa. Cabang Bali yaitu DNI Renon, DNI Kuta, DNI Kedonganan, DNI Sesetan, DNI Gianyar, DNI Tabanan, DNI Singaraja, DNI Karangasem. Cabang Jawa yaitu DNI Jakarta, DNI Lombok, DNI Gresik, DNI Makasar, DNI Malang, dan DNI Tanggerang. Lokasi penelitian dilakukan pada DNI Bali cabang Renon, DNI Skin Centre Renon merupakan klinik pusat DNI yang ada di Bali. Permasalahan yang dihadapi oleh DNI Skin Centre Renon adalah persaingan antar kompetitor sejenis (eksternal faktor) dan terjadi perununan omset perusahaan. Persentase omset perusahaan ditahun 2018 pada bulan Januari - April mencapai 80\% dari $100 \%$ yang ditargetkan sedangkan rata-rata omset perusahaan pada tahun 2019 pada bulan Januari - April pada tahun 2019 baru bisa dicapai sebesar 73,25\%. Omset perusahaan mengalami penurunan sebesar $6,75 \%$. Ketatnya persaingan diperlukan strategi yang tepat untuk dapat mengembangkan usaha. (Nabila et al., 2018).

Strategi perusahaan terdiri dari gerakan pesaing, pendekatan bisnis yang digunakan untuk meningkatkan pertumbuhan perusahaan, dan usaha untuk menarik minat konsumen serta memuaskan konsumen, dan mencapai target yang telah ditetapkan (Thompson., et al, 2006). Salah satu metode yang bisa digunakan untuk merumuskan strategi perusahaan adalah metode analisis SWOT (Andries, 2007). Pada SWOT akan dihasilkan beberapa alternatif strategi, untuk memperoleh prioritas strategi digunakan perhitungan metode TOPSIS. Alternatif strategi yang dihasilkan dari matriks SWOT dipilih yang memiliki jarak terdekat dengan solusi ideal positif dan memiliki jarak terjauh dengan solusi ideal negatif dengan menggunakan metode TOPSIS (Yoon dan Hwang, 1981).

Strategi pengembangan usaha dengan menerapkan metode SWOT dan TOPSIS sudah pernah digunakan dalam penelitian mengenai strategi pengembangan usaha pada perusahaan Barjas Tea dengan hasil prioritas yaitu memastikan bahan baku tersedia tepat waktu dan tepat jumlah. (Juliani et al., 2017). Strategi pengembangan usaha tempura ikan pada skala usaha rumah tangga dengan prioritas strategi yaitu memperluas pasar dengan cara menjualkan produk ke restoran kecil, kantin sekolah, dan juga warung 
makanan (Wirawan et al., 2018). Strategi pengembangan produk produk agroindustri pada area belanja di Agrowisata Cau Chocolate Factory dengan prioritas strategi memperluas pemasaran produk cokelat (Trisnayanti et al., 2019). Penelitian Abidin et al., (2017) mengenai pemilihan strategi pemasaran dengan metode SWOT dan TOPSIS dengan prioritas strategi memperluas jaringan distribusi pemasaran produk. Metode yang digunakan pada penelitian sebelumnya digunakan pada penelitian saat ini, namun topik yang diambil berbeda.

Berdasarkan kemampuan dari metode SWOT yang mampu merumuskan strategi pengembangan usaha serta kemampuan metode TOPSIS untuk menentukan strategi terbaik, maka dilakukan penelitian lebih lanjut mengenai strategi pengembangan usaha DNI Skin Centre Renon. Tujuan penelitin untuk menganalisis kondisi lingkungan internal dan eksternal DNI Skin Centre dan merumuskan strategi serta menetapkan prioritas strategi pengembangan usaha DNI Skin Centre.

\section{METODE PENELITIAN}

\section{Tempat dan Waktu Penelitian}

Penelitian ini dilaksanakan pada perusahaan DNI Skin Centre Renon dan Laboratorium Manajemen Industri FTP. Waktu penelitian dilaksanakan dari bulan Maret - Juni 2019. Penelitian ini dilakukan karena belum pernah dilakukan penelitian mengenai strategi pengembangan usaha di DNI Skin Centre Renon.

\section{Tahapan Penelitian}

Tahapan penelitian ini dimulai dari survei pendahuluan, identifikasi permasalahan serta tujuan, pengumpulan data, identifikasi faktor internal dan eksternal, analisis lingkungan perusahaan, tahap pencocokan, tahap keputusan, alternatif strategi pengembangan usaha. Analisis dan pengolahan data yang digunakan dalam penelitian adalah analisis deskriptif kualitatif dan kuantitatif melalui pendekatan konsep manajemen strategis. Analisis lingkungan perusahaan menggunakan matriks IFE dan EFE, dilanjutkan dengan tahap pencocokkan menggunakan matriks IE dan SWOT (David, 2009). Tahap terakhir yaitu tahap pengambilan keputusan dengan metode TOPSIS (Yoon dan Hwang, 1981).

Alat analisis yang digunakan yaitu Matriks IFE digunakan untuk mengevaluasi faktor-faktor internal yang dimiliki oleh perusahaan (kekutan dan kelemahan), Matriks EFE digunakan untuk mengevaluasi faktor-faktor eksternal yang dihadapi oleh perusahaan (peluang dan ancaman). Tahap pencocokkan yaitu penyusunan matriks IE, matriks IE didasarkan oleh nilai IFE pada sumbu $\mathrm{X}$ dan nilai EFE pada sumbu $\mathrm{Y}$. Dilanjutkan dengan penyusunan strategi dengan matriks SWOT, matriks SWOT menghasilkan 4 jenis sel alternatif strategi yaitu strengths-opportunities (S-O), strengths-threats (S-T), weaknessopportunities (W-O), dan weakness-threats (W-T). Berdsarkan penelitian Abidin et al. (2017), terdapat 6 langkah-langkah penelitian dengan menggunakan metode TOPSIS, yaitu: 1) membuat matriks keputusan alternatif, 2) menghitung matriks keputusan ternormalisasi; 3) menghitung matriks keputusan ternormalisasi terbobot; 4) menentukan matriks solusi ideal positif dan solusi ideal negatif; 5) menentukan nilai jarak setiap alternatif dengan matriks solusi ideal positif dan matriks solusi ideal negatif; 6) menghitung nilai preferensi setiap alternatif.

\section{HASIL DAN PEMBAHASAN}

\section{Analisis Lingkungan Perusahaan Analisis Lingkungan Internal}

Lingkungan internal perusahaan merupakan faktor yang berada di dalam 
perusahaan (Kotler, 2009). Faktor internal dikategorikan kedalam lima aspek yaitu:

1. Poduksi

DNI Skin Centre memiliki 2 macam produk yaitu produk jadi dan produk setengah jadi. Produk yang terdapat di DNI Skin Centre yaitu paket ance series, paket whitening series, paket antiaging series, DNI hand and body lotion, DNI body whitening, DNI damage shampoo. Produk DNI sudah terdaftar di BPOM dengan kode MD. Treatment yang ada pada DNI Skin Centre yaitu sedot lemak, facial, injeksi atau infus pemutih, botox, filler, tanam benang, RF, HIFU, slimming dan pembentuk tubuh, laser penghilang bulu, injeksi rambut ketombe dan kebotakan, angkat tahi lalat atau cauter, perawatan miss v, PRP, laser untuk peremajaan, whitening dan jerawat, microdermabrasi, jet peel, photodinamic therapy.

2. Pemasaran

DNI Skin Centre Renon memiliki website untuk media promosi, DNI juga memiliki akun sosial media seperti instagram, facebook. Kisaran harga produk DNI Skin Centre Renon yaitu dari Rp. 15.000 - Rp. 170.000 per pcs dan rentang harga treatment yaitu $\mathrm{Rp} .100 .000$ - Rp. 1.000.000.

3. Lokasi Industri

DNI Skin Centre Renon berada di pusat kota Denpasar, lokasinya strategis dan dekat dengan konsumen akan memudahkan konsumen untuk datang langung ke klinik. Alamat DNI Skin Centre Renon di J1. Raya Puputan No. 70, Dangin Puri Klod, Kec. Denpasar Timur, Kota Denpasar, Bali.

4. Sumber Daya Manusia (SDM)

Sistem perekrutan SDM di DNI Skin Centre Renon dilakukan oleh HRD dengan melewati proses wawancara terlebih dahulu. Ada beberapa persyaratan untuk SDM DNI salah satunya adalah syarat pendidikan, untuk perawat syaratnya harus minimal D3 keperawatan, untuk apoteker minimal S1 apoteker, untuk staff apotek minimal SMK farmasi, untuk kasir dan accounting minimal SMA/SMK.

5. Keuangan atau Permodalan

Keuangan dari DNI Skin Centre dipegang oleh Direktur Keuangan, pengeluaran dan pemasukan DNI Skin Centre dipegang oleh accounting. Sumber modal dari DNI Skin Centre yaitu berasal dari sumber pribadi dan berasal dari waralaba (frenchise) yang dimiliki oleh DNI, dengan adanya sistem waralaba dapat memperluas jaringan dan diharapkan bisa menguasai menguasai pasar.

\section{Analisis Lingkungan Eksternal}

Menurut Solihin (2012) yang dimaksud dengan lingkungan eksternal perusahaan adalah semua faktor yang berada diluar perusahaan yang harus diperhatikan, karena memiliki potensi untuk mempengaruhi perusahaan. Faktor lingkungan eksternal meliputi aspek yaitu:

1.) Pesaing

Perusahaan sejenis yang menjadi kompetitor dari DNI Skin Centre Renon yaitu Natasha, Estetika, Rudy, ERHA, Renata, Klinik Rahayu, Asih, ZAP dan produk dengan fungsi sejenis yang beredar dipasaran. Peluang dikatakan sebagai ancaman apabila ada pesaing, maka akan terjadi perebutan minat konsumen. Sehingga diperlukan diferensiasi kualitas produk serta kualitas pelayanan yang memberikan ciri khas dimata konsumen.

2.) Eksosbud (ekonomi, sosial dan budaya)

Faktor ekonomi, sosial, budaya memiliki pengaruh penting terhadap daya beli serta pola pembelanjaan konsumen dari DNI Skin Centre. DNI Skin Centre memiliki citra yang baik dimata masyarakat, owner DNI Skin Centre 
merupakan seorang dokter spesialis kulit dan kelamin. Hal tersebut membuat citra perusahaan semakin bagus dimata masyarakat.

3.) Kebijakan Pemerintah

Kewenangan yang dimiliki oleh pemerintah yaitu dalam pembuatan aturan baru. Perubahan dari peraturan pemerintah mengenai perizinan serta peraturan tertentu, mengakibatkan harus diurusnya berkas-berkas baru serta perizinannya. Perizinan suatu badan usaha sangat penting, karena dari perizinan tersebut akan mempengaruhi kepercayaan konsumen terhadap suatu perusahaan. Seperti tercantum pada peraturan Menteri Kesehatan Republik Indonesia No. 1176/MENKES/PER/VIII/2010 tentang Notifikasi Kosmetika.

4.) Bahan Baku

Bahan baku (produk setengah jadi dan produk jadi) dikirim oleh supplier, proses produksi produk DNI terdapat di pulau Jawa. DNI memiliki 5 supplier, produk dikirim ke DNI sebanyak 2 kali dalam satu bulan. Pemasok kadang terlambat mengirim produk yang dipesan oleh DNI karena permintaan produk meningkat, sehingga memerlukan waktu yang lebih lama untuk proses produksi.

\section{Tahap Input (Input Stage)}

Pada tahap input yaitu meringkas informasi dasar yang diperlukan untuk merumuskan strategi. Tahap ini menghasilkan faktor-faktor internal serta eksternal perusahaan. Alat analisis yang digunakan adalah internal factor evaluations (IFE) dan eksternal factor evaluations (EFE).

\section{Analisis Matriks IFE dan Matriks EFE}

Analisis matriks IFE dan EFE dibuat berdasarkan hasil identifikasi kekuatan dan kelemahan sebagai internal factor serta peluang dan ancaman sebagai eksternal factor.

Matriks Internal Faktor Evaluations (IFE)

Hasil analisis matriks IFE dapat dilihat pada Tabel 1. DNI Skin Centre Renon memiliki faktor kekuatan utama yaitu produk yang aman sesuai standar kesehatan, terdaftar di BPOM dengan nilai 0,172. Faktor kelemahan utama yang dimiliki DNI Skin Centre Renon adalah kurangnya informasi mengenai treatment yang ada di DNI Skin Centre Renon dengan nilai 0,124. Hasil matriks IFE menunujukkan total nilai sebesar 3.077 yang berarti bahwa DNI Skin Centre Renon memiliki posisi internal yang kuat dan kompetitif.

Tabel 1. Matriks Internal Factor Evaluations

\begin{tabular}{clccc}
\hline \multicolumn{1}{c}{ KEKUATAN (A) } & $\begin{array}{c}\text { BOBOT } \\
(\mathbf{a})\end{array}$ & $\begin{array}{c}\text { RATING } \\
(\mathbf{b})\end{array}$ & $\begin{array}{c}\text { NILAI (c= } \\
\mathbf{a * b})\end{array}$ \\
\hline 1 & Lokasi strategis di pusat kota & 0.047 & 3.4 & 0.161 \\
2 & Brand produk terkenal & 0.043 & 3.2 & 0.138 \\
3 & Proses pemasaran yang tertata dan berjalan dengan baik & 0.043 & 3.0 & 0.129 \\
4 & Mudah mempromosikan produk, karena figur owner & 0.041 & 3.0 & 0.123 \\
5 & sebagai dokter Sp.KK & 0.041 & 3.8 & 0.156 \\
6 & Sumber modal yang kuat & 0.043 & 3.4 & 0.147 \\
7 & Kerjasama staff yang cukup solid dan baik guna mencapai & 0.043 & 3.2 & 0.138 \\
8 & tujuan perusahaan & 0.045 & 3.2 & 0.145 \\
9 & Kelayanan sesuai dengan SOP & 0.043 & 3.4 & 0.147 \\
10 & Dokter profesional dan sesuai dengan bidangnya & 0.050 & 3.4 & 0.169 \\
11 & Produk yang aman sesuai standar kesehatan, terdaftar di & 0.054 & 3.2 & 0.172 \\
\cline { 3 - 4 } & BPOM & & & \\
\hline
\end{tabular}




\begin{tabular}{rllll}
\hline 12 & Banyak pilihan treatment yang bisa dipilih oleh konsumen & 0.043 & 3.2 & 0.138 \\
13 & $\begin{array}{l}\text { Harga produk dan promo yang bisa bersaing dengan } \\
\text { kompetitor }\end{array}$ & 0.041 & 3.0 & 0.123 \\
& $\begin{array}{l}\text { Satu-satunya klinik skin Centre di Bali yang memiliki } \\
\text { treatment sedot lemak }\end{array}$ & 0.037 & 2.6 & 0.095 \\
15 & Catatan rekam medis menggunakan sistem ikonik & 0.043 & 3.0 & 0.129 \\
\hline \multicolumn{2}{c}{ KELEMAHAN (B) } & & \\
\hline \multirow{2}{*}{$\begin{array}{l}\text { Kurangnya informasi mengenai treatment yang ada di DNI } \\
\text { Skin Centre Renon }\end{array}$} & 0.039 & 3.2 & 0.124 \\
2 & Antri terlalu lama pada jam efektif & 0.039 & 2.8 & 0.109 \\
3 & Bahan baku terkadang terlambat dikirim oleh supplier & 0.041 & 2.6 & 0.106 \\
4 & Belum ada brand pouch untuk konsumen baru & 0.034 & 2.4 & 0.083 \\
5 & Staff belum mempunyai rasa memiliki terhadap klinik DNI & 0.039 & 2.8 & 0.109 \\
6 & Ketrampilan dokter masih belum merata & 0.037 & 3.2 & 0.117 \\
7 & Alur pelayanan pasien belum jelas & 0.039 & 2.6 & 0.101 \\
8 & Pengoperasian sistem ikonik belum maksimal & 0.041 & 3.0 & 0.123 \\
9 & Belum ada display produk OTC (over the counter) di & 0.034 & 2.8 & 0.097 \\
\hline apotek & & & 3.077 \\
\hline
\end{tabular}

\section{Matriks Eksternal Faktor Evaluations (EFE)}

Hasil analisis matriks EFE dapat dilihat pada Tabel 2. DNI Skin Centre Renon memiliki faktor peluang utama yaitu belum banyak yang membuka konsultasi dokter secara grartis dengan nilai 0,344. Faktor ancaman utama yang dihadapi oleh DNI Skin
Centre Renon adalah adanya kompetitor sejenis yang terdekat dengan promo bervariasi dengan nilai 0,248 . Hasil matriks EFE menunjukkan total nilai sebesar 3,066 yang berarti bahwa DNI Skin Centre Renon memiliki respon yang bagus terhadap peluang yang ada dan perusahaan cukup efektif dalam mengantisipasi setiap ancaman.

Tabel 2. Matriks Eksternal Factor Evaluation

\begin{tabular}{|c|c|c|c|c|}
\hline & PELUANG (A) & $\begin{array}{c}\text { BOBOT } \\
\text { (a) }\end{array}$ & $\begin{array}{l}\text { RATING } \\
\text { (b) }\end{array}$ & $\begin{array}{l}\text { NILAI } \\
(\mathbf{c}=\mathbf{a} * \mathbf{b})\end{array}$ \\
\hline 1 & Populasi penduduk di Bali semakin meningkat & 0.079 & 3.6 & 0.284 \\
\hline 2 & Pendapatan perkapita di bali semakin meningkat & 0.079 & 3.2 & 0.252 \\
\hline 3 & Iklim di Indonesia tropis, memerlukan perlindungan kulit & 0.075 & 3.2 & 0.239 \\
\hline 4 & Tingkat polusi yang tinggi di daerah perkotaan & 0.079 & 3.2 & 0.252 \\
\hline 5 & $\begin{array}{l}\text { Meningkatknya kesadaran wanita dan pria untuk kesehatan } \\
\text { kulit dan rambut }\end{array}$ & 0.095 & 3.4 & 0.324 \\
\hline 6 & $\begin{array}{l}\text { Kemajuan dalam teknik perawatan kulit dan produk } \\
\text { kecantikan }\end{array}$ & 0.087 & 3.2 & 0.279 \\
\hline 7 & $\begin{array}{l}\text { Banyak acara adat Bali, secara tidak langsung } \\
\text { megharuskan untuk tampil dengan makeup }\end{array}$ & 0.071 & 3.2 & 0.226 \\
\hline 8 & Belum banyak yang membuka konsultasi dokter secara grartis & 0.095 & 3.6 & 0.344 \\
\hline \multicolumn{5}{|c|}{ ANCAMAN (B) } \\
\hline 1 & Adanya produk substitusi & 0.079 & 2.8 & 0.221 \\
\hline 2 & $\begin{array}{l}\text { Banyaknya isu malpraktek atau penggunaan bahan kimia } \\
\text { berbahaya di Indonesia }\end{array}$ & 0.079 & 2.6 & 0.205 \\
\hline 3 & $\begin{array}{l}\text { Adanya kompetitor sejenis yang terdekat dengan promo } \\
\text { bervariasi }\end{array}$ & 0.095 & 2.6 & 0.248 \\
\hline
\end{tabular}




\begin{tabular}{|c|c|c|c|c|}
\hline 4 & $\begin{array}{l}\text { Konsumen DNI yang mengalami alergi pada saat } \\
\text { menggunakan produk DNI Skin Centre }\end{array}$ & 0.087 & 2.2 & 0.192 \\
\hline & $\begin{array}{ll}\text { TOTAL }(\mathrm{A}+\mathrm{B}) \\
\end{array}$ & & & 3.066 \\
\hline
\end{tabular}

\section{Tahap Pencocokkan (Matching Stage)}

Pada tahap pencocokkan digunakan matriks IE, matriks IE diperoleh dari hasil penggabungan matriks IFE dan matriks EFE. Berdasarkan pada matriks IE dapat dilihat bahwa sumbu-x (nilai total IFE) sebesar 3,077 dan sumbu-y (nilai total EFE) sebesar 3,066. Skala ini menunjukkan bahwa DNI Skin Centre Renon berada pada kuadran I. Strategi pada kuadran I yaitu tumbuh dan bina (growth and build). Strategi tumbuh dan bina menunjukkan bahwa perusahaan sedang bertumbuh dan berkembang. Posisi perusahaan pada kuadran I menggambarkan bahwa perusahaan berada pada kondisi internal kuat dan eksternal tinggi. Strategi yang tepat untuk diaplikasikan adalah strategi intensif (penetrasi pasar, pengembangan pasar dan pengembangan produk) atau strategi integratif (integrasi ke depan, ke belakang dan horizontal).

\begin{tabular}{|c|c|c|c|}
\hline $\begin{array}{ll}\mathrm{EFE}=3,066 & \text { IFE }=3,077 \\
\end{array}$ & $\begin{array}{c}\text { KUAT } \\
(3,00-4,00)\end{array}$ & $\begin{array}{c}\text { RATA-RATA } \\
(2,00-2,99)\end{array}$ & $\begin{array}{l}\text { LEMAH } \\
(1,00-1,99)\end{array}$ \\
\hline $\begin{array}{c}\text { TINGGI } \\
(3,00-4,00) \\
\end{array}$ & $\left.\mathrm{I}\right|_{(3,07 ; 3,066)}$ & II & III \\
\hline $\begin{array}{l}\text { SEDANG } \\
(2,00-2,99)\end{array}$ & IV & V & VI \\
\hline $\begin{array}{l}\text { RENDAH } \\
(1,00-1,99)\end{array}$ & VII & VIII & IX \\
\hline
\end{tabular}

Gambar 1. Hasil Analisis Matriks IE Pada DNI Skin Centre Renon

\section{Analisis Matriks SWOT}

Berdasarkan analisis matriks SWOT didapatkan sembilan alternatif strategi yang bisa diterapkan pada perusahaan. Strategi pada matriks SWOT DNI Skin Centre Renon dapat dilihat pada Tabel 3. Alternatif strategi yang dihasilkan pada matriks SWOT dimasukkan kedalam strategi yang telah dirumuskan pada matriks IE yaitu tumbuh dan bina, sebagai berikut:

\section{Strategi Penetrasi Pasar}

Strategi penetrasi pasar yang direkomendasikan yaitu strategi pertama menggunakan figur owner sebagai seorang dokter Sp.KK untuk menjadi brand ambasador DNI Skin Centre $\left(\mathrm{S}-\mathrm{O}_{2}\right)$. Strategi penetrasi kedua yaitu mempromosikan produk dan treatment yang ada di DNI Skin Centre Renon (W$\mathrm{O}_{3}$ ). Strategi penetrasi ketiga yaitu mempertahankan harga dan kualitas produk $\left(\mathrm{S}-\mathrm{T}_{1}\right)$.

2. Strategi Pengembangan Pasar
Strategi pengembangan pasar yaitu memasarkan produk jadi DNI Skin Centre Renon melalui toko-toko kosmetik (S-O $\left.\mathrm{O}_{1}\right)$.

3. Strategi Pengembangan Produk atau Jasa

Strategi pengembangan produk atau jasa yang direkomendasikan adalah mengadakan pelatihan kepada staff dan dokter DNI Skin Centre Renon $\left(\mathrm{W}-\mathrm{O}_{2}\right)$. Strategi kedua yaitu dengan membuat sistem antrian pasien $\left(\mathrm{W}-\mathrm{O}_{3}\right)$. Strategi ketiga yaitu dengan memberikan edukasi kepada konsumen mengenai produk dan treatment DNI Skin Centre Renon (S- $\left.\mathrm{T}_{2}\right)$. Strategi keempat yaitu mengelola customer Centre dengan baik (W-T $\left.\mathrm{T}_{1}\right)$.

4. Strategi Integrasi Kedepan

Strategi integrasi kedepan yang direkomendasikan yaitu memasarkan produk jadi DNI Skin Centre Renon melalui toko-toko kosmetik (S-T $)_{1}$.

5. Strategi Integrasi Kebelakang

Strategi integrase kedepan yang direkomendasikan yaitu melakukan 
perencanaan persediaan produk $\left(\mathrm{W}-\mathrm{O}_{4}\right)$.

Hasil perumusan strategi DNI Skin

Centre Renon dapat dilihat pada Tabel 3.

\section{Tahap Keputusan}

Tahap keputusan penentuan pemilihan prioritas strategi pada DNI Skin Centre Renon menggunakan metode TOPSIS (Technique for Order of Preference by Similarity to Ideal Solution). Pada perhitungan TOPSIS memerlukan kriteria dan alternatif yang menjadi dasar untuk menentukan prioritas strategi pengembangan usaha. Alternatif strategi pengembangan usaha dirumuskan berdasarkan kondisi lingkungan internal dan eksternal perusahaan. Alternatif strategi dapat dilihat pada Tabel 4. Perhitungan TOPSIS membutuhkan kriteria untuk mengukur kinerja dari setiap alternatif strategi yang dipilih. Pada penelitian ini, kriteia yang digunakan adalah faktor-faktor strategis yang dihasilkan dari analisis faktor lingkungan internal (IFE) dan analisis faktor lingkungan eksternal (EFE). Kriteria yang digunakan dapat dilihat pada Tabel 5.

Tabel 4. Alternatif Strategi DNI Skin Centre Renon

\begin{tabular}{|c|c|c|}
\hline Alternatif & Keterangan & $\begin{array}{c}\text { Nilai } \\
\text { Preferensi }\end{array}$ \\
\hline Strategi 1 (A1) & $\begin{array}{l}\text { Memasarkan produk jadi DNI Skin Centre Renon melalui toko- } \\
\text { toko kosmetik }\end{array}$ & 0.692 \\
\hline Strategi 2 (A2) & $\begin{array}{l}\text { Menggunakan figur owner sebagai dokter SPkk. untuk menjadi } \\
\text { brand ambasador DNI Skin Centre }\end{array}$ & 0.647 \\
\hline Strategi 3 (A3) & Mempertahankan harga dan kualitas produk & 0.757 \\
\hline Strategi 4 (A4) & $\begin{array}{l}\text { Memberikan edukasi kepada konsumen mengenai produk dan } \\
\text { treatment DNI Skin Centre Renon }\end{array}$ & 0.980 \\
\hline Strategi 5 (A5) & $\begin{array}{l}\text { Mempromosikan produk dan treatment yang ada di DNI Skin } \\
\text { Centre Renon }\end{array}$ & 0.721 \\
\hline Strategi 6 (A6) & $\begin{array}{l}\text { Mengadakan pelatihan kepada staff dan dokter DNI Skin Centre } \\
\text { Renon }\end{array}$ & 0.542 \\
\hline Strategi 7 (A7) & Membuat sistem antrian pasien & 0.458 \\
\hline Strategi 8 (A8) & Melakukan perencanaan persediaan bahan baku & 0.503 \\
\hline Strategi 9 (A9) & Mengelola customer Centre dengan baik & 0.316 \\
\hline
\end{tabular}

Tabel 5. Kriteria Matriks SWOT

\begin{tabular}{ccccccccc}
\hline \multicolumn{2}{c}{ Kriteria } & Bobot & \multicolumn{2}{c}{ Kriteria } & Bobot & \multicolumn{2}{c}{ Kriteria } & Bobot \\
\hline C1 & S1 & 0,047 & C13 & S13 & 0,041 & C25 & O1 & 0,079 \\
C2 & S2 & 0,043 & C14 & S14 & 0,037 & C26 & O2 & 0,079 \\
C3 & S3 & 0,043 & C15 & S15 & 0,043 & C27 & O3 & 0,075 \\
C4 & S4 & 0,041 & C16 & W1 & 0,039 & C28 & O4 & 0,079 \\
C5 & S5 & 0,041 & C17 & W2 & 0,039 & C29 & O5 & 0,095 \\
C6 & S6 & 0,043 & C18 & W3 & 0,041 & C30 & O6 & 0,087 \\
C7 & S7 & 0,043 & C19 & W4 & 0,034 & C31 & O7 & 0,071 \\
C8 & S8 & 0,045 & C20 & W5 & 0,039 & C32 & O8 & 0,095 \\
C9 & S9 & 0,043 & C21 & W6 & 0,037 & C33 & T1 & 0,079 \\
C10 & S10 & 0,050 & C22 & W7 & 0,039 & C34 & T2 & 0,079 \\
C11 & S11 & 0,054 & C23 & W8 & 0,041 & C35 & T3 & 0,095 \\
C12 & S12 & 0,043 & C24 & W9 & 0,034 & C36 & T4 & 0,087 \\
\hline
\end{tabular}


Tabel 3. Matriks SWOT

\begin{tabular}{|c|c|c|}
\hline Eksternal & \begin{aligned} \multicolumn{1}{c}{ KEKUATAN (S) } \\
1. Lokasi strategis di pusat kota \\
2. Brand produk terkenal \\
3. Proses pemasaran yang tertata dan \\
berjalan dengan baik \\
4. Mudah mempromosikan produk, \\
karena figur owner sebagai dokter \\
SpKK \\
5. Sumber modal yang kuat \\
6. Memiliki sistem pemsaran waralaba \\
7. Kerjasama staff yang cukup solid \\
dan baik guna mencapai tujuan \\
perusahaan \\
8. Pelayanan sesuai dengan SOP \\
9. Konsultasi diberikan secara gratis \\
10. Dokter profesional dan sesuai \\
dengan bidangnya \\
11. Produk yang aman sesuai standar \\
kesehatan, terdaftar di BPOM \\
12. Banyak pilihan treatment yang bisa \\
dipilih oleh konsumen \\
13. Harga produk dan promo yang bisa \\
bersaing dengan kompetitor \\
14. Satu-satunya klinik kecantikan di \\
Bali yang memiliki treatment sedot \\
lemak \end{aligned} & $\begin{array}{l}\text { KELEMAHAN (W) } \\
\text { 1. Kurangnya informasi mengenai } \\
\text { treatment yang ada di DNI Skin } \\
\text { Centre Renon } \\
\text { 2. Antri terlalu lama pada jam efektif } \\
\text { 3. Bahan baku terkadang terlambat } \\
\text { dikirim oleh supplier } \\
\text { 4. Belum ada brand pouch untuk } \\
\text { konsumen baru } \\
\text { 5. Staff belum mempunyai rasa } \\
\text { memiliki terhadap klinik DNI } \\
\text { 6. Ketrampilan dokter masih belum } \\
\text { merata } \\
\text { 7. Alur pelayanan pasien belum jelas } \\
\text { 8. Pengoperasian sistem ikonik } \\
\text { belum maksimal } \\
\text { 9. Belum ada display produk OTC } \\
\text { (over the counter) di apotek }\end{array}$ \\
\hline $\begin{array}{l}\text { PELUANG (O) } \\
\text { 1. Populasi penduduk di Bali semakin } \\
\text { meningkat } \\
\text { 2. Pendapatan perkapita di bali semakin } \\
\text { meningkat } \\
\text { 3. Iklim di Indonesia tropis, memerlukan } \\
\text { perlindungan kulit } \\
\text { 4. Tingkat polusi yang tinggi di daerah } \\
\text { perkotaan } \\
\text { 5. Meningkatknya kesadaran wanita dan } \\
\text { pria untuk kesehatan kulit dan rambut } \\
\text { 6. Kemajuan dalam teknik perawatan } \\
\text { kulit dan produk kecantikan } \\
\text { 7. Banyak acara adat Bali, secara } \\
\text { tidak langsung megharuskan } \\
\text { untuk tampil dengan makeup } \\
\text { 8. Belum banyak yang membuka } \\
\text { konsultasi dokter secara grartis }\end{array}$ & \begin{tabular}{ll}
\multicolumn{1}{c}{$\mathbf{S}-\mathbf{O}$} \\
1.
\end{tabular} & \begin{tabular}{ll}
\multicolumn{1}{c}{$\mathbf{W}-\mathbf{O}$} \\
1. \\
Mempromosikan produk dan \\
treatment yang ada di DNI Skin \\
Centre Renon (W1, W4, O1, O3, \\
O4, O5, O6) \\
2. Mengadakan pelatihan kepada \\
staff dan dokter DNI Skin Centre \\
Renon (W5, W6, W8, O5, O6) \\
3. Membuat sistem antrian pasien \\
(W2, W7, O8) \\
4. Melakukan perencanaan \\
persediaan bahan baku (W3, O1, \\
O5
\end{tabular} \\
\hline \begin{tabular}{l} 
ANCAMAN (T) \\
\multicolumn{1}{c}{ ANA } \\
1. Adanya produk substitusi \\
2. Banyaknya isu malpraktek atau \\
penggunaan bahan kimia berbahaya di \\
Indonesia \\
3. Adanya kompetitor sejenis yang \\
terdekat dengan promo bervariasi \\
4. Konsumen DNI yang mengalami alergi \\
pada saat menggunakan produk DNI \\
Skin Centre
\end{tabular} & $\begin{array}{l}\text { S }-\mathbf{T} \\
\text { 1. Mempertahankan harga dan kualitas } \\
\text { produk (S2, S3, S5, S11, S13, S14, } \\
\text { T1, T3) } \\
\text { 2. Memberikan edukasi kepada } \\
\text { konsumen mengenai produk dan } \\
\text { treatment DNI Skin Centre Renon } \\
\text { (S8, S9, S10, S11, S12, T2, T4) }\end{array}$ & $\begin{array}{l}\text { W-T } \\
\text { 1. } \begin{array}{l}\text { Mengelola customer } \\
\text { dengan baik (W1, T4) }\end{array}\end{array}$ \\
\hline
\end{tabular}

\section{Menentukan Nilai Preferensi Setiap Alternatif}

Nilai preferensi dipergunakan untuk menentukan prioritas strategi dari alternatif strategi. Nilai preferensi berdasarkan pada nilai jarak setiap alternatif terhadap solusi ideal positif dan solusi ideal negatif. Hasil perangkingan alternatif DNI Skin Centre Renon dapat dilihat pada Gambar 2. 


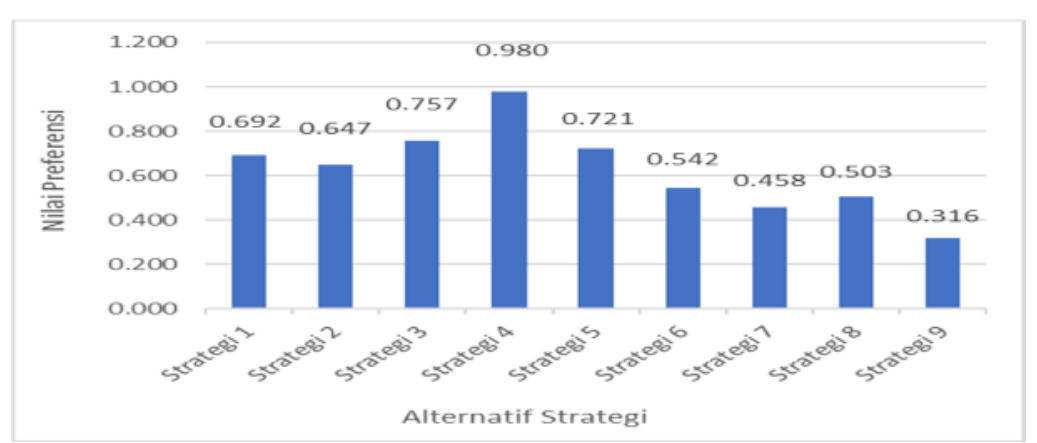

Gambar 2. Hasil Perangkingan Alternatif DNI Skin Centre Renon

Berdasarkan pada hasil perangkingan alternatif, bahwa alternatif strategi keempat adalah strategi terbaik karena memiliki nilai terbesar yaitu 0,982. Dapat diambil keputusan bahwa strategi keempat yaitu memberikan edukasi kepada konsumen mengenai produk dan treatment DNI Skin Centre Renon merupakan alternatif strategi yang akan dijadikan pertimbangan utama sebagai strategi untuk mengembangkan usaha DNI Skin Centre Renon.

\section{KESIMPULAN DAN SARAN}

\section{Kesimpulan}

Berdasarkan penelitian ini dapat disimpulkan sebagai berikut :

1. DNI Skin Centre Renon memiliki 15 faktor kekuatan dan 9 faktor kelemahan. Nilai analisis IFE DNI Skin Centre Renon berada pada posisi yang kuat menghadapi segala kelemahan. Kekuatan utamanya adalah produk yang aman sesuai standar kesehatan, terdaftar di BPOM sedangkan kelemahan utamanya adalah kurangnya informasi mengenai treatment yang ada di DNI Skin Centre Renon. DNI Skin Centre Renon memiliki 8 faktor peluang dan 4 faktor ancaman. Berdasarkan nilai EFE DNI Skin Centre Renon berada pada posisi kuat dalam mengatasi ancaman yang datang dari luar dengan cara memanfaatkan peluang yang dimiliki. Peluang utamanya yaitu belum banyak usaha sejenis yang membuka konsultasi dokter secara gratis. Ancaman utamanya yaitu adanya kompetitor sejenis yang terdekat dengan promo bervariasi.

2. Strategi yang bisa digunakan oleh DNI Skin Centre Renon adalah tumbuh dan bina yaitu terdiri dari strategi intensif (penetrasi pasar, pengembangan pasar, dan pengembangan produk) atau integrasi (integrasi ke depan, integrasi ke belakang, dan integrasi horizontal). Berdasarkan alternatif-alternatif dari matriks SWOT diperoleh 9 strategi untuk mengembangkan DNI Skin Centre Renon. Prioritas strategi terpilih yaitu memberikan edukasi kepada konsumen mengenai produk dan treatment DNI Skin Centre Renon. Prioritas strategi kedua yaitu mempertahankan harga dan kualitas produk dan prioritas strategi ketiga yaitu mempromosikan produk dan treatment yang ada di DNI Skin Centre Renon

\section{Saran}

Saran yang bisa diberikan berdasarkan hasil penelitian yang telah dilakukan yaitu DNI Skin Centre Renon dapat menerapkan strataegi tumbuh dan kembangkan yang terdiri dari intensif (penetrasi pasar, pengembangan pasar, pengembangan produk) atau integrasi (integrasi ke depan, integrasi ke belakang, integrasi horizontal), serta menerapkan prioritas strategi terpilih yaitu memberikan 
edukasi kepada konsumen mengenai produk dan treatment DNI Skin Centre Renon.

\section{DAFTAR PUSTAKA}

Abidin, M. Z., I. Masudin dan D.M. Utama. 2017. Pemilihan Strategi Pemasaran Dengan Metode SWOT Dan TOPSIS. Jurnal Teknik Industri. 18(1):55-67.

Andries, F.R. 2007. Perumusan Strategi Pemasaran Berdasarkan Analisis SWOT Studi Kasus Pada PT. Waringin Puspanusa Lestari Jakarta. Skripsi. Tidak Dipublikasikan. Fakultas Ekonomi UNS, Yogyakarta.

David, F.R. 2009. Strategic Management (Manajemen Strategis Konsep). Salemba Empat, Jakarta.

Juliani, K.A.M., B.A. Harsojuwono dan I.K. Satriawan. 2017. Strategi Pengembangan Usaha Minuman Barjaz Tea di Barjaz Company. Jurnal Rekayasa Dan Manajemen Agroindustri. 5(4):41-50.

Kementrian Kesehatan Republik Indonesia. 2010. Peaturan Menteri Kesehatan Republik Indonesia Nomor 1176/MENKES/PER/VIII/2010

Tentang Notifikasi Kosmetik. http://ngada.org/bn397-2010.htm. Diakses pada tanggal 14 September 2019.

Kotler, P. 2009.Manajemen Pemasaran. Erlangga, Jakarta.

Manurung, L. 2010. Strategi Dan Inovasi Model Bisnis Meningkatkan Kinerja Usaha, Studi Empiris Industri Penerbangan.PT. Gramedia. Jakarta.

Nabila, N., G. Janti dan P.S, Fadil. 2018. Analisis Deskriptif Pengguna Kosmetik Aktif di Surabaya. 7(1). 2337-3520.
Solihin, I. 2012. Manajemen Strategik. Erlangga, Jakarta.

Thompson, A.A., A.J, Strickland III., and J.E, Gamble. 2006. Crafting and executing strategy: The quest for competitive advantage. McGraw-Hill. New York.

Tranggono, R. I., dan L, Fatma. (2007). Buku Pegangan Ilmu Pengetahuan Kosmetik. PT Gramedia Pustaka Utama, Jakarta

Trisnayanti, N.M., I. K. Satriawan., dan I.W. G. S. Yoga. 2019. Strategi Pengembangan Produk Agroindustri Pada Area Belanja Di Agrowisata Cau Chocolate Factory. Jurnal Rekayasa dan Manajemen Agroindustri. 7(2):220-228.

Wirawan, N. Z. M., A. A. P. S. Wiranatha., dan A. Hartiati. 2018. Strategi Pengembangan Usaha Produksi Tempura Ikan Pada Skala Usaha Rumah Tangga (Studi Kasus Tempura Ikan X Kota Denpasar, Bali). Jurnal Rekayasa Dan Manajemen Agroindustri. 6(1):57-70.

Yoon, K and C.L. Hwang. 1981. Multiple Attribute Decision Making: Methods and Applications. Springer-Verlag. New York. 